\title{
Anti-IGF-1R Recombinant Monoclonal Antibody BIIB022
}

National Cancer Institute

\section{Source}

National Cancer Institute. Anti-IGF-1R Recombinant Monoclonal Antibody BIIB022. NCI

Thesaurus. Code C71530.

A recombinant, human monoclonal antibody directed ag ainst the insulin-like growth factor 1 receptor (IGF-1R) with potential antineoplastic activity. Anti-IGF-1R recombinant monoclonal antibody BIIB022 binds to membrane-bound IGF-1R, preventing binding of the ligand IGF-1 and the subsequent triggering of the PI3K/Akt signaling pathway; inhibition of this survival signaling pathway may result in the inhibition of tumor cell proliferation and the induction of tumor cell apoptosis. The activation of IGF-1R, a tyrosine kinase and a member of the insulin receptor family, stimulates cell proliferation, enables oncogenic transformation, and suppresses apoptosis; IGF-1R signaling has been highly implicated in tumorigenesis and metastasis. 